\title{
Factor Factor Kepuasan Pasien Terhadap Proses Keperawatan
}

\author{
Indah Pandiangan \\ Indahpandiangan13@gmail.com
}

\section{latarbelakang}

Pelayanan keperawatan yang berkualitas menjadi faktor penentu tingkat kepuasan pasien. Pelayanan keperawatan yang diberikan semakin baik akan meningkatkan kepuasan pasien. Pelayanan keperawatan sebagai lini terdepan berperan sangat tinggi atas kepuasan yang diterima oleh pasien. Ketidakpuasan pasien terhadap pelayanan keperawatan baik di Indonesia maupun di negara berkembang lainnya saat ini masih menjadi masalah. Data kepuasan pasien di salah satu rumah sakit umum daerah di Indonesia didapatkan 70\% pasien kurang puas terhadap pelayanan keperawatan. Ketidakpuasan pasien saat dirawat di rumah sakit disebabkan oleh beberapa faktor. Faktor kesalahan identitas masih sering terjadi yaitu kekeliruan identitas pasien terutama di unit perawatan intensif, ruang operasi, dan keadaan darurat. Faktor komunikasi, penyebab terbanyak dikarenakan kesalahan dari penerapan keselamatan pasien. Kerugian yang terjadi sebagai akibat tidak dipedulikannya keselamatan pasien cukup banyak.

Standar kepuasan pasien di pelayanan kesehatan ditetapkan secara nasional oleh Departemen Kesehatan. Menurut Peraturan Kementrian Kesehatan Republik Indonesia Tahun 2016 tentang Standar Pelayanan Minimal untuk kepuasan pasien yaitu diatas 95\%. Bila ditemukan pelayanan kesehatan dengan tingkat kepuasaan pasien berada dibawah 95\%, maka dianggap pelayanan kesehatan yang diberikan tidak memenuhi standar minimal atau tidak berkualitas.

Asuhan keperawatan yang berkualitas karena perawat berinteraksi langsung selama 24 jam dengan pasien, dan jumlah perawat yang mendominasi sehingga perawat harus mampu memberikan pelayanan keperawatan yang bermutu. Oleh karena itu pelayanan keperawatan memiliki kontribusi yang besar dalam meningkatkan mutu pelayanan rumah sakit. 


\section{Metode}

Desain penelitian mengunakan desain analitik korelasi dengan pendekatan cross sectional. Penerapan metode tim keperawatan yang baik akan berdampak kepada kualitas dokumentasi asuhan keperawatan yang dibuat oleh responden.Apabila metode tim yang dijalankan oleh perawat di Ruang Asoka tidak baik atau masihkurang dampaknya akan terlihat pada kualitas dokumentasi asuhan keperawatan yang dibuatnya.

pelayanan keperawatan untuk pasien rawat inap memerlukan adanya manajemen pada setiap ruangan, apabila manajemen keperawatan tidak berjalan dengan baik maka akan berpengaruh terhadap kepuasan pasien. Hal ini bahwa ada hubungan yang bermakna antara mutu pelayanan keperawatan yang menggunakan metode tim terhadap kepuasan pasien di ruang rawat inap. Pencatatanproses keperawatan merupakan metode yang tepat untuk pengambilan keputusan yang sistematis, pemecahan masalah dan riset lebih lanjut. Standar dokumentasi berguna untuk memperkuat pola pencatatan dan sebagai petunjuk atau pedoman praktik pendokumentasian dalam memberikan tindakan keperawatan.

Menurut Carpenito (1991) dalam Pujiastuti (2012) perawat harus memegang 3 prinsip dalam meningkatkan keterampilan membuat dokumentasi keperawatanyaitu brevity (ringkas, tidak perlu memasukkan kata-kata yang tidak penting), legibility (mudah dibaca dan dipahami), dan yang terakhir acurracy (benar dan sesuai dengan data yang diperoleh). Seorang perawat dalam menerapkan metode tim keperawatan harus membuat dokumentasi asuhan keperawatan, agar metode tim tersebut benar-benar dijalankan dalam sebuah pelayanan keperawatan.Faktor lain yang menyebabkan tidak berjalannya metode tim dipengaruhi oleh kebijakan rumah sakit yang tidak mendukung pelaksanaan metode tim misalnya kurangnya pelatihan dan sosialisasi, selain itu kurangnya jumlah ketenagaan perawat untuk melaksanakan metode tim mengenai metode tim.Sedangkan sarana prasarana yang kurang mendukung pelaksanaan metode tim seperti peralatan medis yang kurang memadai, tidak adanya aula perawat untuk mengadakan diskusi memecahkan masalah dan pasien.

\section{Hasil}

Kualitas pelayanan memiliki hubungan yang erat dengan kepuasan pasien, dimana kualitas memberikan suatu dorongan kepada pasien untukmenjalin ikatan hubungan yang kuat dengan 
pihak di Puskesmas Wisata Dau Malang. Kualitas pelayanan merupakan setiap kegiatan atau manfaat yang diberikan oleh pihak layanan kesehatan kepada pasien yang pada dasarnya menyelamatkan nyawa dan mempercepat penyembuhan segala penyakit yang diderita pasien. Kepuasan pasien salah satu tindakan keberhasilan perawat dalam membina hubungan baik dengan pasien melalui teknik dan sikap yang baik selama memberikan asuhan keperawatan kepada pasien.

Penelitian ini membuktikan kualitas pelayanan memiliki hubungan yang signifikan untuk meningkatkan kepuasan pasien. Kepuasan pasien merupakan kebutuhan mendasar bagi penyedia layanan kesehatan, kepuasan pasien menjadi patokan untuk keputusan pengambilan keputusan dimasa yang akan datang. Pelayanan dibidang kesehatan akan senantiasa selalu mengalami perkembangan ke arah yang lebih baik. Pada dasarnya pelayanan kesehatan diperlukan oleh setiap orang untuk keperluan kesehatanya, maka diharapkan kualitas pelayanan yang baik dapat menumbuhkan dan mempengaruhi keputusan dan kepercayaan pasien demi menimbulkan kepuasan pasien untukmenggunakan jasa layanan kesehatan. Kepuasan pasien terjadi apabila apa yang menjadi kebutuhan, keinginan, atau harapannya dapat terpenuhi. Harapan tersebut dapat terpenuhi melalui pelayanan kesehatan yang diterima olehnya. Oleh karena itu kepuasan pasien dihasilkan dari layanan yang diterima pasien sesuai dengan harapan yang diinginkannya. Kepuasaan pasien menjadi bagian integral dalam misi dan tujuan profesi keperawatan karena semakin meningkatnya intensitas kompetensi global dan domestik akan meningkatkan pelayanan jasa keperawatan yang bermutu.

\section{Pembahasan}

Aspek kepuasan pasien yang belum optimal terutama pada dimensi kehandalan yaitu perawat tidak selalu memberikan petunjuk pada tindakan yang akan dilakukan selanjutnya.

\section{Hubungan Karakteristik Pasien dengan Kepuasan Pasien}

Umur. Pada penelitian ini tidak ditemukan adanya hubungan antara umur dengan kepuasan pasien. Hal ini sejalan dengan penelitian menyatakan bahwa tidak hanya umur pasien yang memengaruhi kepuasan tetapi dipengaruhi aspek yang lain. Kepuasan dipengaruhi oleh umur. Semakin tua umur emosionalnya akan lebih terkontrol, lebih dapat menerima keterbatasan fisik dari pada orang yang lebih muda. Hal ini karena orang usia tua usia tua tuntutan dan harapannya 
lebih rendah dari pasien usia muda. hal ini disebabkan oleh nilai-nilai budaya sebagai orang tua dihormati, diberikan hak-hak istimewa dari generasi muda sehingga memengaruhi perawat lebih memperhatikan orang tua daripada anak muda. Pasien yang lebih tua umumnya lebih merasa puas dibandingkan dengan yang lebih muda. Pasien yang lebih tua akan merasa puas dengan pelayanan di rumah sakit karena harapannya lebih rendah.

Jenis KelaminPenelitian menunjukkan tidak ada hubungan jenis kelamin dengan kepuasan pasien. Responden antara laki-laki dan perempuan akan relatif sama dalam menilai kepuasan pelayanan. Hasil penelitian lain menunjukkan laki-laki lebih merasa puas dalam pelayanan keperawatan di rumah sakit dibandingkan dengan perempuan. Penelitian ini, menyatakan bahwa pelayanan keperawatan yang dirasakan pasien laki-laki lebih merasa puas dibandingkan dengan pasien perempuan di salah satu rumah sakit daerah. Pasien perempuan lebih merasa puas dengan pelayanan perawatan dibanding dengan pasien laki-laki. Persepsi dan reaksi terhadap gangguan sakit dipengaruhi oleh jenis kelamin, ras, pendidikan, kelas ekonomi, dan latar belakang budaya, yang memengaruhi penilaian kepuasan pasien. Pasien perempuan lebih merasa puas Pelayanan keperawatan yang dirasakan pasien laki-laki lebih merasa puas dibandingkan dengan pasien perempuan.

Pendidikan. Hasil penelitian menunjukkan tidak ada hubungan bermakna antara pendidikan pasien dengan kepuasan pasien. Perasaan puas pada setiap individu tidaklah sama, akan tetapi ungkapan puas pada sekelompok individu dapat terjadi hampir sama karena adanya pengaruh lingkungan dan masyarakat golongan tertentu. Kepuasan pasien tidak hanya dipengaruhi oleh pendidikan yang tinggi akan tetapi pengaruh lingkungan, golongan masyarakat, pendidikan non formal di lingkungannya, pengalaman hidup seseorang, berkontribusi pada penilaian tingkat kepuasan pasien. Kepuasan pasien tidak hanya dipengaruhi oleh pendidikan formal, tetapi lingkungan juga memengaruhi Pendidikan pasien tidak berpengaruh pada penilaian kepuasan terhadap pelayanan keperawatan di rumah sakit. Tingkat pendidikan pasien tidak memengaruhi kepuasan pasien pada pelayanan keperawatan Pasien di Negara maju memberikan penilaian yang berbeda level pendidikan yang lebih rendah cenderung kurang kritis sehingga kepuasannya lebih tinggi Pasien dengan level pendidikan yang rendah memiliki kepuasan yang lebih tinggi dibandingkan dengan pasien yang memiliki level pendidikan tinggi. Hal ini disebabkan pasien dengan level pendidikan yang lebih tinggi bisa mengakses informasi terkait perawatannya di 
rumah sakit sehingga dapat membandingkan perawatan yang diterima dengan informasi yang diketahui, pasien menjadi tidak puas.

Pekerjaan. Hasil penelitian menunjukkan tidak ada hubungan bermakna pekerjaan dengan kepuasaan pasien. Meskipun pasien tidak bekerja cenderung merasa lebih puas dibanding pasien bekerja. Penelitian sejalan bahwa Pemberian pelayanan profesional kepada pasien dengan tidak membedakan antara pasien bekerja maupun tidak bekerja dapat merasakan kepuasan yang sama. Pasien paling banyak pada kategori tidak bekerja. Pasien tidak bekerja adalah pensiunan, ibu rumah tangga dan tidak bekerja. Rumah sakit juga menyediakan pelayanan bagi pengguna asuransi kesehatan mulai dari asuran BPJS dan asuransi swasta sehingga pasien tidak bekerja dapat mendapatkan pelayanan kesehatan. Penelitian tidak sejalan bahwa pekerjaan menentukan tingkat kepuasan pasien, pasien yang bekerja lebih merasa puas terhadap pelayanan keperawatan yang diterima saat dirawat di RS dibandingkan dengan pasien yang tidak bekerja. Pendapatan rumah tangga (pekerjaan) yang memadai memengaruhi tingkat kepuasan pasien pada pelayanan kesehatan yang diterima di rumah sakit. Pelayanan keperawatan dirasakan pada pasien yang belum bekerja dan pasien ibu rumah tangga memiliki skor kepuasan lebih rendah dibandingkan dengan pasien bekerja sebagai pegawai pemerintah.

Kelas Perawatan. Hasil penelitian ini tidakditemukan adanya hubungan kelas perawatan dengan kepuasan pasien. Penelitian sejalan bahwa variabel kelas perawatan tidak ada perbedaan yang signifikan dalam menilai kepuasan pelayanan keperawatan. Kelas perawatan tidak menentukan tingkat kepuasan pasien, dimana kepuasan pasien ditentukan oleh kinerja dari perawat pemberi Pelayanan keperawatan pasien tidak dipengaruhi kelas rawat. Perawat memberikan pelayanan secara profesional pada semua pasien dengan tidak membedakan status sosialnya. Penelitian tidak sejalan bahwa kelas perawatan pasien berhubungan tingkat kepuasan. Seseorang yang memiliki status sosial ekonomi yang baik berkesempatan untuk menggunakan dan mendapatkan fasilitas pelayanan yang lebih baik daripada pasien yang memiliki sosial ekonomi rendah. Status sosial ekonomi memengaruhi pemilihan kelas rawat pasien di rumah sakit.

Hubungan Penerapan Keselamatan Pasien dengan Kepuasan Pasien. Hasil penelitian menunjukkan ada hubungan bermakna antara penerapan keselamatan pasien oleh perawat dengan kepuasan pasien. Penelitian lain tentang penerapan keselamatan pasien oleh perawat dihubungkan dengan kepuasan pasien belum ditemukan oleh peneliti baik di Indonesia maupun 
di negara maju yang lainnya. Penelitian pada aspek identifikasi ada hubungan bermakna antara identifikasi pasien secara benar dengan kepuasan pasien. identifikasi pasien sangat penting untuk membedakan pasien yang satu dengan yang lain Penelitian pada aspek komunikasi terdapat hubungan dengan kepuasan pasien, Semakin baik komunikasi yang dilaksanakan maka semakin puas pasien dalam pelayanan keperawatan. Berdasarkan hal tersebut dapat disimpulkan,bahwa komunikasi terapeutik berhubungan dengan kepuasan pasien. Pada aspek penerapan ketepatan obat dengan kepuasan pasien ditemukan hubungan, Pasien merasa puas pada pemberian obat yang diberikan tepat waktu, diberikan penjelasan manfaat dan efek samping obat. Penelitian pada aspek menurunkan risiko infeksi terdapat hubungan dengan kepuasan pasien, risiko terinfeksi terjadi karena perawat berperan dalam mencegah risiko infeksi yang terjadi di rumah sakit. Kepuasan pasien sangat dipengaruhi oleh sikap dan pendekatan perawat di rumah sakit kepada pasien, mutu pelayanan keperawatan yang diterima pasien. Tindakan perawat dalam hal ini adalah tindakan yang berkaitan dengan 6 standar keselamatan pasien.

\section{Penutup}

Proses keperawatan merupakan metode dalam memecahkan masalah keperawatan yang bersifat terbuka dan fleksibel dalam memenuhi kebutuhan pasien dengan memberikan asuhan keperawatan dengan dilakukan secara sistematis sehingga meningkatkan kualitas pelayanan keperawatan.

\section{Daftar pustaka}

1. Astuti Normailida (2019). Factor factor hubungan penerapan terhadap keperawatan, ners jurnal keperawatan, volume 1, hal 70-72

2. Widiasari, Hanny dkk (2019). Kepuasan pasien terhadap penerapan keselamatan pasien di RS, jurnal keperawatan Indonesia, volume 2(nomor 2) hal 47-49

3. Sri Purwanti, Swito dkk (2017). Hubungan pelayanan perawat dengan kepuasan pasien, nursing news, volume 2 (nomor 2) hal 690

4. Yunianti (2016). Factor factor yang mempengaruhi kepuasan pasien di rumah sakit, skripsi, hal 1-3

5. Nany Librianty (2017). Factor factor yang mempengaruhi kepuasan pasien terhadap pelayanan kesehatan, jurnal kesehatan masyarakat, volume 1 (nomor 2) hal 12-15 
6. Mokhammad Arifin, Sumitri (2013). Tingkat kepuasan pasien, jurnal ilmiah kesehatan, volume 2 (nomor 2) hal 2

7. Panggabean Nabila Salsabila (2012). Hubungan keperawatan dengan kepuasan pelayanan keperawatan, jurnal keperawatan, volume 2, hal 3

8. Arifah Mutia Saroh (2019). Proses keperawatan sebagai metode keperawatan, hal 2-5

9. Allen, C. V. (2015). Memahami proses keperawatan Jakarta : EGC

10. Nursalam (2017). Proses dan dokumentasi keperawatan, volume 2 (nomor 2), hal 4

11. Simamora, R. H. (2019). Development of Guidelines for Applying appropriate Patient Identification to Achieve Patient Safety Goal

12. INC2019 12th International Nursing Conference. 2019.10455 - 455 (1 pages) UCI(KEPA) : I410-ECN-0101-2019-512-001224337

13. Simamora. R. H. (2008) The correlation of ward chief's giving direction and command and the performance of on-duty nurses at Jember dr. Subandi general hospital inpatient wards. jurnal Administrasi dan Kebijakan Kesehatan, (https://fkm.unair.ac.id/jurnaladministr) 